\title{
Assessment of the Safety of Olmesartan in Combination with Sorafenib in Mice Bearing Ehrlich's Ascites Carcinoma
}

\author{
Mohammad M. Abd-Alhaseeb ${ }^{1 *}$, Sawsan A. Zaitone ${ }^{2}$, Soad H. Abou-El-Ela ${ }^{3}$, Yasser M. Moustafa ${ }^{2}$ \\ ${ }^{1}$ Department of Pharmacology and Toxicology, Faculty of Pharmacy \& Pharmaceutical Industries, Sinai University, Arish, Egypt; \\ ${ }^{2}$ Department of Pharmacology and Toxicology, Faculty of Pharmacy, Suez Canal University, Ismailia, Egypt; ${ }^{3}$ Department of Bio- \\ chemistry, Faculty of Pharmacy \& Pharmaceutical Industries, Sinai University, Arish, Egypt. \\ Email: ${ }^{*}$ m.abdelhasseb@su.edu.eg
}

Received September $17^{\text {th }}, 2013$; revised October $14^{\text {th }}, 2013$; accepted October $22^{\text {nd }}, 2013$

Copyright (C) 2013 Mohammad M. Abd-Alhaseeb et al. This is an open access article distributed under the Creative Commons Attribution License, which permits unrestricted use, distribution, and reproduction in any medium, provided the original work is properly cited.

\begin{abstract}
Sorafenib was the first multikinase inhibitor to be approved for use in metastatic renal cell carcinoma. Olmesartan medoxomil used in treatment of hypertension and was reported to inhibit angiogenesis in several models. The present study was designed to assess the safety of a combination of sorafenib plus olmesartan compared to monotherapies in mice bearing Ehrlich's ascites carcinoma cell line. Mice were divided to seven groups, 1) normal mice, 2) Ehrlich's ascites carcinoma control, 3 - 5) olmesartan $(3,10,30 \mathrm{mg} / \mathrm{kg} /$ day $)$, respectively, 6) sorafenib (30 mg/kg/day) and 7) the combination group: mice received olmesartan $(30 \mathrm{mg} / \mathrm{kg} / \mathrm{day})$ plus sorafenib. All drug treatments continued for 21 days. At the end of the experiment, a complete blood count was performed and kidney and liver functions were estimated. The combination therapy produced a non-significant change in most of the measurements of complete blood count and liver enzymes when compared to normal animals. On the other hand, the combined therapy significantly increased blood urea nitrogen when compared to normal group but did not change the serum creatinine level. Concomitant administration of olmesartan with sorafenib did not significantly augment the toxicity of the later. Therefore; olmesartan might be a safe candidate with sorafenib in treatment of cancer if clinical data proved the benefit of this combination.
\end{abstract}

Keywords: Mice; Ehrlich's Ascites Carcinoma; Olmesartan; Sorafenib

\section{Introduction}

Sorafenib was the first multikinase inhibitor to be approved for use in metastatic renal cell carcinoma in the US (2005) and in Europe (2006) [1]. Sorafenib (Nexavar) significantly prolonged the progression-free survival in 903 patients versus placebo [2]. Sorafenib is an oral, biaryl urea RAF kinase inhibitor that acts against both vascular endothelial growth factor (VEGF) and plateletderived growth factor receptors, simultaneously targeting both tumor cell proliferation and angiogenesis $[3,4]$. In contrast to the traditional adverse effects from cytotoxic chemotherapeutic agents, sorafenib seems to have a distinct adverse effect profile. It has been shown to increase the risk of hypertension, bleeding, hand-foot discoloration, arterial thromboembolism, and elevated liver transa-

\footnotetext{
"Corresponding author.
}

minases [5]. Thrombocytopenia and other hematologic toxicities have been reported in some clinical trials using sorafenib [6]. The exact etiology of these toxic responses is still unclear [7].

Angiotensin receptor blockers (ARBs) are widely used as antihypertensive drugs [8]. Olmesartan medoxomil was introduced as selective angiotensin II receptor blocker used in treatment of hypertension [9]. In addition, ARBs inhibit VEGF, so it can be used to inhibit angiogenesis. In our laboratory (unpublished data), we found that olmesartan potentiated the anti-angiogenic effect of sorafenib in mice bearing Ehrlich's ascites carcinoma (EAC) cell line.

The objective of the current study was to assess some of the toxic effects of a three-week therapeutic period using a combination of sorafenib plus olmesartan compared to monotherapies in mice bearing EAC cell line. 


\section{Materials and Methods}

\subsection{Chemicals}

Olmesartan medoxomil was purchased from Daiichi Sankyo Pharmaceutical Co. (Tokyo, Japan) and dissolved in dimethylsulfoxide (DMSO) supplied by SigmaAldrich (MO, USA). Sorafenib tosylate was purchased from Bayer AG (Leverkusen, Germany) and dissolved in DMSO. Urea colorimetric kit was purchased from Biodiagnostic $^{\circledR}$ (Cairo, Egypt). Creatinine colorimetric kit was purchased from Diamond Diagnostic ${ }^{\circledR}$ (Cairo, Egypt). SGPT (ALT) and SGOT (AST) colorimetric kits were purchased from BioSTC ${ }^{\circledR}$ (Cairo, Egypt). All other chemicals were of analytical grade and were purchased from ADWIC Co. (Cairo, Egypt).

\subsection{Tumor Cell Line and Induction of Solid Tumor}

Ehrlich's ascites carcinoma cell line was purchased from Tumor Biology Department at the National Cancer Institute, Cairo University (Cairo, Egypt). The EAC cells were suspended in normal saline to obtain a diluted suspension; each $0.1 \mathrm{ml}$ of this suspension contained 2.5 million of EAC cells. Each mouse was inoculated intradermally at both sites on the lower ventral side with 100 $\mu \mathrm{l}$ of EAC suspension.

\subsection{Animals and Experimental Design}

All the experimental protocols were approved by the Animal Care and Use Committee at Faculty of Pharmacy, Suez Canal University, Ismailia, Egypt. Forty nine female Swiss albino mice, each weighing 20 - $25 \mathrm{~g}$ were obtained from the Modern Veterinary Office for Laboratory Animals, Cairo, Egypt. All animals were allowed to acclimatize under standard animal house conditions fourteen days prior to assignment to the experimental protocol. Animals were fed on a standard pellet diet, and allowed free access to tap water. They were kept at a temperature of $22^{\circ} \mathrm{C} \pm 3^{\circ} \mathrm{C}$ and constant relative humidity throughout the experimental protocol.

Mice were randomly divided into seven groups, seven mice each. Mice received the following treatments. Group I: mice received DMSO (5 ml/kg, p.o.) and served as a normal control group. Group II: EAC-bearing mice received DMSO (5 ml/kg, p.o.) and served as a positive control group. Group III: mice were treated with sorafenib (30 mg/kg/day, p.o.) [10]. Group IV: mice were treated with olmesartan (3 mg/kg/day, p.o.) [11]. Group $\mathrm{V}$ : mice were treated with olmesartan $(10 \mathrm{mg} / \mathrm{kg} / \mathrm{day}$, p.o.). Group VI: mice were treated with olmesartan (30 $\mathrm{mg} / \mathrm{kg} /$ day, p.o.). Group VII: mice received a combination of sorafenib (30 mg/kg/day, p.o.) and olmesartan (30 $\mathrm{mg} / \mathrm{kg} /$ day, p.o.). All treatments started at day 8 and continued for 21 days (the therapeutic period was three weeks).

\subsection{Percentage Survival of Animals and Body Weight}

Percentage survival of animals was followed daily and calculated in each group as: [Number of living animals/ initial total number of animals] $\times 100$. Body weight of each mouse was registered before treatments (base line body weights) and at the end of experiment (final body weights). In addition, the percent change in animal weights was calculated.

\subsection{Blood Collection and Assessment of Hematological Parameters}

Fresh blood samples $(1 \mathrm{ml})$ were collected in a tube containing either ethylenediaminetetraacetic acid solution ( $29 \mu \mathrm{g} / \mathrm{ml}$ blood) for complete blood count (CBC). Samples were analyzed within $2 \mathrm{~h}$ in an automated cell counter (Cell-DYN 1700, Model: CD-1700, ABOTT Diagnostics, USA). Thirty min after collection, blood samples were centrifuged at $2000 \times g$ for $15 \mathrm{~min}$. Another blood sample was withdrawn and collected in a dry centrifuge tube and allowed to stand for $30 \mathrm{~min}$. After that, blood samples were processed by centrifugation at $2000 \times g$ for $15 \mathrm{~min}$. Then, serum samples were separated, collected in clean tubes and stored at $-80^{\circ} \mathrm{C}$ until used for colorimetric assays.

\subsection{Assessment of Serum ALT \& AST Enzymes}

Alanine aminotransferase (ALT) and aspartate aminotransferase (AST) catalyzed the transfer of an amino group between the amino acids L-alanine and L-aspartate, respectively [12]. The ketoacids formed-pyruvate and oxaloacetic acid, respectively-reacted with diazonium salt to form a colored complex. The optical density foe this colored product was measured at $505-530 \mathrm{~nm}$ using a spectrophotometer (UV-1601PC, Schimadzu, Japan).

\subsection{Assessment of Serum Creatinine and Blood Urea Nitrogen}

Creatinine assessment based on its reaction with sodium picrate [13]. Creatinine reacted with alkaline picrate forming a red complex. The intensity of the color formed is proportional to the creatinine concentration in the sample. Blood urea nitrogen (BUN) assessment was measured where urea in the sample by urease enzyme give a colored complex [14]. The developed colored complex measured at $530-560 \mathrm{~nm}$ using a spectrophotometer (UV-1601PC, Schimadzu, Japan).

\subsection{Statistical Analysis}

Results are expressed as mean \pm S.E.M. Data were ana- 
lyzed using one-way analysis of variance, ANOVA, followed by Bonferroni's post-hoc test. All statistical tests were performed employing the Statistical Package for Social Sciences, version 19 (SPSS Software, SPSS Inc., Chicago, USA) and the differences were considered significant at $\mathrm{P}<0.05$.

\section{Results}

\subsection{Percentage Survival of Animals and Animal Body Weights}

The percentage survival of animals showed a significant decrease in all groups when compared to normal group. However, the combined therapy showed a significant (P $<0.05)$ increase in percentage survival of animals in comparison with EAC-control and olmesartan $(10 \mathrm{mg} / \mathrm{kg})$ groups (Table 1).

There were no significant differences among the study groups at the beginning of the study. However, EACcontrol group showed a significant increase in percentage body weight gain compared to normal group $(\mathrm{P}<0.05$, Table 1). After three-week therapeutic period, sorafenib decreased animal weight and the percentage body weight gain compared to normal and EAC-control group. Furthermore, treatment with olmesartan ( 3 and $10 \mathrm{mg} / \mathrm{kg}$ ) produced a non-significant difference compared to the normal group but showed significant differences from both EAC-control and sorafenib group. Additionally, olmesartan $(30 \mathrm{mg} / \mathrm{kg})$ produced a significant $(\mathrm{P}<0.05)$ decrease in percentage body weight compared to EACcontrol and sorafenib groups (Table 1). In addition, the combination therapy did not producea significant change in percentage body weight compared to normal group but produced a significant change in comparison to EACcontrol group and sorafenib group $(\mathrm{P}<0.05)$.

\subsection{Hematological Parameters}

Tables 2 and 3 demonstrate hematological changes ob- served after treating mice with sorafenib, different doses of olmesartan, as well as their combination. The results showed that sorafenib significantly $(\mathrm{P}<0.05)$ reduced RBCs, Hgb, Hct, RDW, platelet count, MPV, Pct, PDW, lymphocytes and monocytes when compared to normal control group (Tables 2 and 3). On the other hand, different doses of olmesartan $(3,10$ and $30 \mathrm{mg} / \mathrm{kg})$ did not produced a significant change in almost all hematological parameters when compared to normal control group. This with the exception of the effect of olmesartan on \% PDW; where olmesartan ( 3 and $30 \mathrm{mg} / \mathrm{kg}$ ) produced a significant reduction in \% of PDW while olmesartan $(10 \mathrm{mg} / \mathrm{kg})$ produced a significant increase in the (Tables 2 and $\mathbf{3}$ ). Further, olmesartan $(30 \mathrm{mg} / \mathrm{kg})$ produced a significant increase in $\%$ of Pct when compared to normal control group.

Furthermore, the combination therapy of olmesartan with sorafenib produced non-significant changes in the complete blood count when compared to normal control except in case of RDW\%; the combination therapy produced a significant reduction in RDW\% while the combination produced a significant increase in Pct $\%$ and PDW\% which indicate the safety of the two drugs when used with each other. In addition, the combined therapy produced a significant increase in lymphocytes when compared to normal, EAC-control, sorafenib and olmesartan (3 and $30 \mathrm{mg} / \mathrm{kg}$ ) groups (Table 3).

\subsection{Serum ALT and AST Enzymes}

Liver transaminases (AST/ALT) are biomarkers which indicated the degree of liver injury caused by any chemical substances or pathogens. Liver enzymes are significantly $(\mathrm{P}<0.05)$ increased in EAC-Control group when compared to normal control group (Table 4). On the other hand, sorafenib significantly $(\mathrm{P}<0.05)$ increased ALT enzyme only when compared to normal group while AST enzyme non-significantly increased. Olmesartan ( 3 and $30 \mathrm{mg} / \mathrm{kg}$ ) did not produced any sig-

Table 1. Effect of sorafenib (30 mg/kg/day, p.o.) and/or olmesartan (3, 10 and $30 \mathrm{mg} / \mathrm{kg} / \mathrm{day}$, p.o.) on animal weights and percentage survival in EAC-bearing mice.

\begin{tabular}{|c|c|c|c|c|c|c|c|}
\hline & Normal & EAC-Control & $\begin{array}{c}\text { Sorafenib } \\
(30 \mathrm{mg} / \mathrm{kg})\end{array}$ & $\underset{(3 \mathrm{mg} / \mathrm{kg})}{\text { Olmesartan }}$ & $\begin{array}{c}\text { Olmesartan } \\
(10 \mathrm{mg} / \mathrm{kg})\end{array}$ & $\begin{array}{c}\text { Olmesartan } \\
(30 \mathrm{mg} / \mathrm{kg})\end{array}$ & $\begin{array}{c}\text { Sorafenib + } \\
\text { Olmesartan } \\
(30 \mathrm{mg} / \mathrm{kg})\end{array}$ \\
\hline Body weight (baseline) & $24 \pm 0.43$ & $23 \pm 0.75$ & $24 \pm 1.35$ & $24 \pm 0.48$ & $22 \pm 0.69$ & $23 \pm 0.51$ & $24 \pm 1.21$ \\
\hline Body weight (final) & $29 \pm 0.43$ & $34 \pm 0.51^{\mathrm{a}}$ & $19 \pm 0.26^{\mathrm{ab}}$ & $26 \pm 0.92^{\mathrm{bc}}$ & $26 \pm 0.53^{\mathrm{bc}}$ & $25 \pm 1.30^{\mathrm{abc}}$ & $27 \pm 0.77^{\mathrm{bc}}$ \\
\hline$\% \Delta w t(g)$ & $21 \pm 1.86$ & $47 \pm 4.65^{\mathrm{a}}$ & $-20 \pm 3.9^{\mathrm{ab}}$ & $12 \pm 6.31^{\mathrm{bc}}$ & $16 \pm 2.61^{\mathrm{bc}}$ & $9 \pm 7.34^{\mathrm{bc}}$ & $12 \pm 6.57^{\mathrm{bc}}$ \\
\hline$\%$ survival of animals & $98 \pm 2$ & $50 \pm 5.5^{\mathrm{a}}$ & $62 \pm 0.8^{\mathrm{a}}$ & $63 \pm 0.3^{\mathrm{a}}$ & $52 \pm 0.2^{\mathrm{a}}$ & $63 \pm 4.3^{\mathrm{a}}$ & $74 \pm 4.7^{\mathrm{abf}}$ \\
\hline
\end{tabular}

EAC-control: Ehrlish ascites carcinoma control. Mice were treated with the selected drugs for three weeks. Results are expressed as mean \pm S.E.M. and analyzed using one-way ANOVA followed by Bonferroni's post-hoc test. ${ }^{\mathrm{a}} \mathrm{P}<0.05$ compared to normal group, ${ }^{\mathrm{b}} \mathrm{P}<0.05$ compared to EAC-Control group, ${ }^{\mathrm{c}} \mathrm{P}<$ 0.05 compared to Sorafenib $(30 \mathrm{mg} / \mathrm{kg})$ group. ${ }^{\mathrm{d}} P<0.05$ compared to olmesartan $(30 \mathrm{mg} / \mathrm{kg}) .{ }^{\mathrm{e}} P<0.05$ compared to olmesartan $(3 \mathrm{mg} / \mathrm{kg})$ group. ${ }^{\mathrm{f}} P<0.05$ compared to olmesartan $(10 \mathrm{mg} / \mathrm{kg})$ group. 
Table 2. Effect of sorafenib (30 mg/kg/day, p.o.) and/ or olmesartan $(3,10$ and $30 \mathrm{mg} / \mathrm{kg} / \mathrm{day}$, p.o.) on complete blood count in EAC-bearing mice

\begin{tabular}{|c|c|c|c|c|c|c|c|}
\hline & $\begin{array}{l}\text { Normal } \\
\text { control }\end{array}$ & EAC-Control & $\begin{array}{l}\text { Sorafenib } \\
(30 \mathrm{mg} / \mathrm{kg})\end{array}$ & $\begin{array}{c}\text { Olmesartan } \\
(3 \mathrm{mg} / \mathrm{kg})\end{array}$ & $\begin{array}{c}\text { Olmesartan } \\
(10 \mathrm{mg} / \mathrm{kg})\end{array}$ & $\begin{array}{c}\text { Olmesartan } \\
(30 \mathrm{mg} / \mathrm{kg})\end{array}$ & $\begin{array}{c}\text { Sorafenib + } \\
\text { Olmesartan } \\
(30 \mathrm{mg} / \mathbf{k g})\end{array}$ \\
\hline $\operatorname{RBC}(M / \mu L)$ & $9 \pm 0.53$ & $7 \pm 0.54$ & $6 \pm 0.11^{\mathrm{a}}$ & $8 \pm 0.26$ & $8 \pm 0.42$ & $7 \pm 0.41$ & $8 \pm 0.07$ \\
\hline Hgb (g/dl) & $12 \pm 0.38$ & $10 \pm 0.97$ & $8 \pm 0.06^{\mathrm{a}}$ & $11 \pm 0.66$ & $12 \pm 0.85^{\mathrm{c}}$ & $10 \pm 0.64$ & $12 \pm 0.15^{\mathrm{c}}$ \\
\hline Het (\%) & $36 \pm 1.02$ & $31 \pm 1.59$ & $24 \pm 0.34^{\mathrm{a}}$ & $34 \pm 1.75^{\mathrm{c}}$ & $42 \pm 2.36^{\text {bce }}$ & $29 \pm 1.87^{\mathrm{f}}$ & $35 \pm 0.94^{\mathrm{cf}}$ \\
\hline MCV (fL) & $38 \pm 1.15$ & $44 \pm 2.35$ & $38 \pm 0.63$ & $31 \pm 2.31^{\mathrm{b}}$ & $48 \pm 1.17^{\text {ace }}$ & $39 \pm 2.56^{\mathrm{ef}}$ & $44 \pm 1.31^{\mathrm{e}}$ \\
\hline MCH (Pg) & $14 \pm 0.68$ & $15 \pm 0.38$ & $13 \pm 0.28^{b}$ & $14 \pm 0.35$ & $15 \pm 0.45$ & $14 \pm 0.45$ & $15 \pm 0.05^{\mathrm{c}}$ \\
\hline $\operatorname{MCHC}(\mathrm{g} / \mathrm{dl})$ & $34 \pm 1.85$ & $34 \pm 1.63$ & $34 \pm 0.47$ & $34 \pm 2.92$ & $31 \pm 1.86$ & $36 \pm 3.01$ & $34 \pm 1.22$ \\
\hline RDW (\%) & $16 \pm 0.21$ & $14 \pm 0.77$ & $12 \pm 0.17^{\mathrm{a}}$ & $14 \pm 0.52$ & $15 \pm 0.39^{\mathrm{c}}$ & $15 \pm 0.81^{\mathrm{c}}$ & $13 \pm 0.38^{\mathrm{a}}$ \\
\hline Platelet $(\mathrm{K} / \mu \mathrm{L})$ & $624 \pm 6.17$ & $660 \pm 20.76$ & $490 \pm 2.57^{\mathrm{ab}}$ & $624 \pm 24.57^{\mathrm{c}}$ & $630 \pm 20.84^{\mathrm{c}}$ & $619 \pm 2.43^{\mathrm{c}}$ & $641 \pm 14.14^{\mathrm{c}}$ \\
\hline MPV (fL) & $9.3 \pm 0.4$ & $10 \pm 0.64$ & $6 \pm 0.19^{\mathrm{ab}}$ & $8 \pm 0.5^{\mathrm{b}}$ & $9 \pm 0.3$ & $9 \pm 0.72^{\mathrm{c}}$ & $9.4 \pm 0.57^{\mathrm{c}}$ \\
\hline Pet (\%) & $0.412 \pm 0.01$ & $0.665 \pm 0.02^{\mathrm{a}}$ & $0.304 \pm 0.01^{\mathrm{ab}}$ & $0.403 \pm 0.02^{\mathrm{bc}}$ & $0.474 \pm 0.02^{\mathrm{bc}}$ & $0.534 \pm 0.02^{\text {abce }}$ & $0.581 \pm 0.02^{\text {abcef }}$ \\
\hline PDW (\%) & $9 \pm 0.55$ & $10 \pm 0.32$ & $2 \pm 0.13^{\mathrm{ab}}$ & $5 \pm 0.41^{\mathrm{abc}}$ & $12 \pm 0.2^{\text {abce }}$ & $7 \pm 0.57^{\text {abcef }}$ & $12 \pm 0.73^{\mathrm{abced}}$ \\
\hline
\end{tabular}

EAC-Control: Ehrlish ascites carcinoma control, RBCs: red blood cells, Hgb: hemoglobin, Hct: hematocrit, MCV: mean corpuscular volume, MCH: mean corpuscular hemoglobin, MCHC: mean corpuscular hemoglobin concentration, RDW: red cell distribution width, MPV: mean platelet volume, Pct: plateletcrit, PDW: platelet distribution width. Mice were treated with the selected drugs for three weeks. Results are expressed as mean \pm S.E.M. and analyzed using oneway ANOVA followed by Bonferroni's post-hoc test. ${ }^{\mathrm{a}} P<0.05$ compared to normal group, ${ }^{\mathrm{b}} P<0.05$ compared to EAC-control group, ${ }^{\mathrm{c}} P<0.05$ compared to sorafenib (30 mg/kg) group. ${ }^{\mathrm{d}} P<0.05$ compared to olmesartan $(30 \mathrm{mg} / \mathrm{kg})$ group. ${ }^{\mathrm{e}} P<0.05$ compared to olmesartan $(3 \mathrm{mg} / \mathrm{kg})$ group. ${ }^{\mathrm{f}} \mathrm{P}<0.05$ compared to olmesartan $(10 \mathrm{mg} / \mathrm{kg})$ group, $n=7$.

Table 3. Effect of sorafenib (30 mg/kg/day, p.o.) and/or olmesartan (3, 10 and $30 \mathrm{mg} / \mathrm{kg} / \mathrm{day}$, p.o.) on leukocyte formula in EAC-bearing mice.

\begin{tabular}{|c|c|c|c|c|c|c|c|}
\hline & Normal & EAC-Control & $\begin{array}{l}\text { Sorafenib } \\
(30 \mathrm{mg} / \mathrm{kg})\end{array}$ & $\begin{array}{l}\text { Olmesartan } \\
(3 \mathrm{mg} / \mathrm{kg})\end{array}$ & $\begin{array}{c}\text { Olmesartan } \\
(10 \mathrm{mg} / \mathrm{kg})\end{array}$ & $\begin{array}{l}\text { Olmesartan } \\
(30 \mathrm{mg} / \mathrm{kg})\end{array}$ & $\begin{array}{c}\text { Sorafenib + Olmesartan } \\
(30 \mathrm{mg} / \mathrm{kg})\end{array}$ \\
\hline WBC $(\mathrm{K} / \mu \mathrm{L})$ & $10 \pm 0.56$ & $12 \pm 0.32$ & $6 \pm 0.06^{\mathrm{b}}$ & $9 \pm 2.13$ & $8 \pm 0.79$ & $7 \pm 0.47^{\mathrm{b}}$ & $8 \pm 0.15$ \\
\hline Lymphocytes (\%) & $81 \pm 1.81$ & $86 \pm 0.89$ & $73 \pm 0.2^{\mathrm{ab}}$ & $85 \pm 3.25^{\mathrm{c}}$ & $87 \pm 0.32^{\mathrm{c}}$ & $84 \pm 0.82^{\mathrm{c}}$ & $92 \pm 0.77^{\text {abced }}$ \\
\hline Neutrophils (\%) & $5 \pm 1.38$ & $6 \pm 1.16$ & $1 \pm .0 .09^{b}$ & $7 \pm 0.94^{\mathrm{c}}$ & $5 \pm .0 .99$ & $4 \pm 0.75$ & $4 \pm 0.15$ \\
\hline Monocytes (\%) & $11 \pm 2.2$ & $6 \pm 1.05$ & $3 \pm 0.31^{\mathrm{a}}$ & $9 \pm 3.13$ & $6 \pm 0.99$ & $8 \pm 1.36$ & $4 \pm 0.2$ \\
\hline
\end{tabular}

EAC-control: Ehrlish ascites carcinoma control, WBC: white blood cells. Mice were treated with the selected drugs for three weeks. Results are expressed as mean \pm S.E.M. and analyzed using one-way ANOVA followed by Bonferroni's post-hoc test. ${ }^{\mathrm{a}} P<0.05$ compared to normal group, ${ }^{\mathrm{b}} P<0.05$ compared to EAC-Control group, ${ }^{\mathrm{c}} P<0.05$ compared to Sorafenib $(30 \mathrm{mg} / \mathrm{kg})$ group. ${ }^{\mathrm{d}} \mathrm{P}<0.05$ compared to olmesartan $(30 \mathrm{mg} / \mathrm{kg})$ group. ${ }^{\mathrm{e}} \mathrm{P}<0.05 \mathrm{compared}$ to olmesartan $(3 \mathrm{mg} / \mathrm{kg})$ group. ${ }^{\mathrm{f}} P<0.05$ compared to olmesartan $(10 \mathrm{mg} / \mathrm{kg})$ group. $n=7$.

Table 4. Effect of sorafenib (30 $\mathrm{mg} / \mathrm{kg})$ and/or olmesartan $(3,10$ and $30 \mathrm{mg} / \mathrm{kg})$ on liver and kidney functions in EAC-bearing mice.

\begin{tabular}{|c|c|c|c|c|c|c|c|}
\hline & $\begin{array}{l}\text { Normal } \\
\text { control }\end{array}$ & EAC-Control & $\begin{array}{c}\text { Sorafenib } \\
(30 \mathrm{mg} / \mathrm{kg})\end{array}$ & $\begin{array}{l}\text { Olmesartan } \\
\text { (3 mg/kg) }\end{array}$ & $\begin{array}{l}\text { Olmesartan } \\
(10 \mathrm{mg} / \mathrm{kg})\end{array}$ & $\begin{array}{l}\text { Olmesartan } \\
(30 \mathrm{mg} / \mathrm{kg})\end{array}$ & $\begin{array}{c}\text { Sorafenib }+ \\
\text { Olmesartan }(30 \mathrm{mg} / \mathrm{kg})\end{array}$ \\
\hline $\operatorname{ALT}(\mathbf{U} / \mathbf{L})$ & $66 \pm 1.29$ & $85 \pm 3.24^{\mathrm{a}}$ & $102 \pm 0.29^{\mathrm{a}}$ & $63 \pm 6.49^{b c}$ & $71 \pm 5.05^{c}$ & $66 \pm 4.03^{b c}$ & $54 \pm 0.87^{\mathrm{bcf}}$ \\
\hline $\operatorname{AST}(\mathbf{U} / \mathbf{L})$ & $90 \pm 0.14$ & $106 \pm 3.39^{\mathrm{a}}$ & $109 \pm 0.14$ & $102 \pm 12.98$ & $116 \pm 3.24^{\mathrm{a}}$ & $108 \pm 2.43$ & $103 \pm 0.71$ \\
\hline BUN (g/dl) & $29 \pm 0.29$ & $40 \pm 1.10^{\mathrm{a}}$ & $45 \pm 2.16^{\mathrm{a}}$ & $50 \pm 2.84^{\mathrm{ab}}$ & $65 \pm 2.13^{\mathrm{abce}}$ & $64 \pm 1.42^{\text {abce }}$ & $43 \pm 0.44^{\mathrm{adf}}$ \\
\hline
\end{tabular}

EAC-Control: Ehrlisch ascities carcinoma control, ALT: alanine aminotransferase, AST: aspartate aminotransferase, BUN: blood urea nitrogen. Mice were treated with the selected drugs for three weeks. Results are expressed as mean \pm S.E.M. and analyzed using ANOVA followed by Bonferroni's multiple comparisons test. ${ }^{\mathrm{a}} \mathrm{P}<0.05$ compared to normal group, ${ }^{\mathrm{b}} \mathrm{P}<0.05$ compared to EAC-Control group, ${ }^{\mathrm{c}} \mathrm{P}<0.05$ compared to Sorafenib $(30 \mathrm{mg} / \mathrm{kg})$. ${ }^{\mathrm{d}} \mathrm{P}<0.05 \mathrm{com}-$ pared to olmesartan $(30 \mathrm{mg} / \mathrm{kg})$ group. ${ }^{\mathrm{e}} \mathrm{P}<0.05$ compared to olmesartan $(3 \mathrm{mg} / \mathrm{kg})$ group. ${ }^{\mathrm{f}} \mathrm{P}<0.05 \mathrm{compared}$ to olmesartan $(10 \mathrm{mg} / \mathrm{kg})$ group, $n=7$. 
nificant $(\mathrm{P}<0.05)$ changes in liver enzymes when compared to normal group while olmesartan $(10 \mathrm{mg} / \mathrm{kg})$ significantly $(\mathrm{P}<0.05)$ increased AST enzyme when compared to normal group (Table 4). The combined therapy produced insignificant effect on liver enzymes when compared to normal group and this indicated the safety of this combined therapy on liver functions.

\subsection{Serum Creatinine \& Blood Urea Nitrogen}

The results showed that sorafenib treatment caused significant increase $(\mathrm{P}<0.05)$ in serum blood urea nitrogen and creatinine when compared to normal group (Table 4). In the same time olmesartan doses produced similar effects. The combined therapy significantly $(\mathrm{P}<0.05)$ increased blood urea nitrogen when compared to normal group but doesn't change creatinine levels (Table 4).

\section{Discussion}

Carcinogenesis leads to several pathologies including hematological complications [15]. Moreover, almost all therapeutic regimens available for cancer generally produce a lot of side effects, including hematological toxicity $[15,16]$. Hematological parameters are routinely monitored during the course of treatment of malignancy for assessing the overall well being as well as the effects of the treatment employed [15]. In the present study we evaluate the toxicity produced after three weeks of treatment with sorafenib or/and olmesartan in mice with Ehrlich's ascites carcinoma (EAC). The result of the current study showed that over a period of three weeks, sorafenib led to decreased RBCs, Hgb, platelets and lymphocytes. In addition, sorafenib increased ALT, blood urea nitrogen and creatinine levels. Consistent with our results, sorafenib has been shown to produce bleeding, anemia and lymphopenia in phase 2 and 3 clinical trials $[2,5,17,18]$.

In addition, hematological toxicities associated with sorafenib have been reported in some clinical trials, but they have not been well documented [5,6]. Another study demonstrated that sorafenib with higher doses aggravated liver injury [19] and this result came in parallel with the previous results in our study. The exact mechanism for the hematological toxicities associated with sorafenib still unclear however, can be explained through the tyrosine kinase inhibition of FLT-3 and c-KIT [5]. FLT-3 is primary expressed on committed myeloid and lymphoid precursors and its activation by FLT ligand plays a critical role in normal hematopioesis and cellular growth [20]. On the other hand, in the current study the treatment with olmesartan reduced mostly all hematological parameters but these changes not significantly from normal animals. In agreement, the stimulation of the angiotensin type 1 receptor by angiotensin II stimulate activities of the erythropoietin, thrombopoietin and other hematopoietic cytokines during normal hematopoiesis and in myeloproliferative neoplasms [21] so blocking of angiotensin type 1 receptor by olmesartan reduced hematological parameters. In the same time olmesartan $(30 \mathrm{mg} / \mathrm{kg})$ produced no significant changed in AST and ALT enzymes when compared to normal animals. In agreement, olmesartan treatment has not been shown to significantly affect liver function testing including AST and ALT enzymes and kidney damage $[8,22]$ and this may be attributed to the antioxidant activity of olmesartan as reported in two studies using olmesartan [23-25].

In the current study, sorafenib produced a significant reduction in animal weight when compared to normal group and this came in parallel with the anorexia produced after sorafenib treatments as reported in some clinical trials [2]. On the other hand, mice treated with olmesartan (3 and $10 \mathrm{mg} / \mathrm{kg}$ ) showed that no significant change in body weight compared to normal ones, however the animals treated with olmesartan $(30 \mathrm{mg} / \mathrm{kg})$ showed a significant reduction in body weight compared to normal ones. Consistent with our results, olmesartan produced reduction in animal weights alone or in combination with pioglitazone [26].

According to the best of our knowledge, the present study was the first to assess the toxic responses produced by the combination of sorafenib plus olmesartan (30 $\mathrm{mg} / \mathrm{kg}$ ). The results showed that this combination did not influence each others in most of the hematological parameters and liver enzymes. However, lymphocytes and creatinine levels significantly increased when compared to normal group. Additionally, the combined therapy did not reduce the animal body weights compared to normal group. Finally, the percentage survival of animals in all groups showed a significant decreased compared to normal group however, the combined therapy showed to some extent minor increased but not significant from the other treated animals.

\section{Conclusion}

Concomitant administration of Olmesartan with sorafenib did not significantly augment the toxicity of the later. The present study suggested that this combination offers no obvious toxicity, thus it might be evolved as a promising regimen for treatment of tumor antihypertensive patients. Further, long-term toxicity studies are needed in order to rule out any long-term adverse effect of the combination.

\section{REFERENCES}

[1] J. Bellmunt, T. Eisen, M. Fishman and D. Quinn, "Experience with Sorafenib and Adverse Event Management," Critical Reviews in Oncology/Hematology, Vol. 78, No. 1, 2011, pp. 24-32.

http://dx.doi.org/10.1016/j.critrevonc.2010.03.006 
[2] N. Bhojani, C. Jeldres, J. J. Patard, P. Perrotte, N. Suardi, G. Hutterer, F. Patenaude, S. Oudard and P. I. Karakiewicz, "Toxicities Associated with the Administration of Sorafenib, Sunitinib, and Temsirolimus and Their Management in Patients with Metastatic Renal Cell Carcinoma," European Urology, Vol. 53, No. 5, 2008, pp. 917930. http://dx.doi.org/10.1016/j.eururo.2007.11.037

[3] S. M. Wilhelm, L. Adnane, P. Newell, A. Villanueva, J. M. Llovet and M. Lynch, "Preclinical Overview of Sorafenib, a Multikinase Inhibitor That Targets Both Raf and VEGF and PDGF Receptor Tyrosine Kinase Signaling," Molecular Cancer Therapeutics, Vol. 7, No. 10, 2008, pp. 3129-3140. http://dx.doi.org/10.1158/1535-7163.MCT-08-0013

[4] J. C. Lin, C. L. Liu, J. J. Lee, T. P. Liu, W. C. Ko, Y. C. Huang, C. H. Wu and Y. J. Chen, "Sorafenib Induces Autophagy and Suppresses Activation of Human Macrophage," International Immunopharmacology, Vol. 15, No. 2, 2013, pp. 333-339.

http://dx.doi.org/10.1016/j.intimp.2013.01.006

[5] F. A. Schutz, Y. Je and T. K. Choueiri, "Hematologic Toxicities in Cancer Patients Treated with the Multi-Tyrosine Kinase Sorafenib: A Meta-Analysis of Clinical Trials," Critical Reviews in Oncology/Hematology, Vol. 80, No. 2, 2011, pp. 291-300. http://dx.doi.org/10.1016/j.critrevonc.2010.11.007

[6] J. M. Llovet, S. Ricci, V. Mazzaferro, P. Hilgard, E. Gane, J. F. Blanc, A. C. de Oliveira, A. Santoro, J. L. Raoul, A. Forner, M. Schwartz, C. Porta, S. Zeuzem, L. Bolondi, T. F. Greten, P. R. Galle, J. F. Seitz, I. Borbath, D. Haussinger, T. Giannaris, M. Shan, M. Moscovici, D. Voliotis, J. Bruix and S. I. S. Group, "Sorafenib in Advanced Hepatocellular Carcinoma," The New England Journal of Medicine, Vol. 359, 2008, pp. 378-390. http://dx.doi.org/10.1056/NEJMoa0708857

[7] L. S. Wood, "Managing the Side Effects of Sorafenib and Sunitinib," Community Oncology, Vol. 3, No. 9, 2006, pp. $558-562$. http://dx.doi.org/10.1016/S1548-5315(11)70751-3

[8] J. A. Brousil and J. M. Burke, "Olmesartan Medoxomil: An Angiotensin II-Receptor Blocker," Clinical Therapeutics, Vol. 25, No. 4, 2003, pp. 1041-1055. http://dx.doi.org/10.1016/S0149-2918(03)80066-8

[9] V. Sukumaran, P. T. Veeraveedu, N. Gurusamy, A. P. Lakshmanan, K. Yamaguchi, M. Ma, K. Suzuki, M. Nagata, R. Takagi, M. Kodama and K. Watanabe, "Olmesartan Attenuates the Development of Heart Failure after Experimental Autoimmune Myocarditis in Rats through the Modulation of ANG 1-7 Mas Receptor," Molecular and Cellular Endocrinology, Vol. 351, No. 2, 2012, pp. 208-219. http://dx.doi.org/10.1016/j.mce.2011.12.010

[10] H. Huynh, J. W. Lee, P. K. Chow, V. C. Ngo, G. B. Lew, I. W. Lam, H. S. Ong, A. Chung and K. C. Soo, "Sorafenib Induces Growth Suppression in Mouse Models of Gastrointestinal Stromal Tumor," Molecular Cancer Therapeutics, Vol. 8, No. 1, 2009, pp. 152-159. http://dx.doi.org/10.1158/1535-7163.MCT-08-0553

[11] M. Tsuda, M. Iwai, J. M. Li, H. S. Li, L. J. Min, A. Ide, M. Okumura, J. Suzuki, M. Mogi, H. Suzuki and M. Horiuchi, "Inhibitory Effects of AT1 Receptor Blocker,
Olmesartan, and Estrogen on Atherosclerosis via AntiOxidative Stress," Hypertension, Vol. 45, No. 4, 2005, pp. 545-551. http://dx.doi.org/10.1161/01.HYP.0000157409.88971.fc

[12] F. J. Gella, T. Olivella, M. Cruz Pastor, J. Arenas, R. Moreno, R. Durban and J. A. Gomez, "A Simple Procedure for the Routine Determination of Aspartate Aminotransferase and Alanine Aminotransferase with Pyridoxal Phosphate," Clinica Chimica Acta, Vol. 153, No. 3, 1985, pp. 241-247. http://dx.doi.org/10.1016/0009-8981(85)90358-4

[13] M. Peake and M. Whiting, "Measurement of Serum Creatinine-Current Status and Future Goals," The Clinical Biochemist Reviews, Vol. 27, 2006, pp. 173-184.

[14] M. A. Hamed, N. S. El-Rigal and S. A. Ali, "Effects of Black Seed Oil on Resolution of Hepato-Renal Toxicity Induced Bybromobenzene in Rats," European Review for Medical and Pharmacological Sciences, Vol. 17, 2013, pp. 569-581.

[15] S. R. Gangar and A. Koul, "Effects of Azadirachta Indica on Certain Hematological Parameters during Benzo(a)pyrene Induced Murine Forestomach Tumorigenesis," European Review for Medical and Pharmacological Sciences, Vol. 14, 2010, pp. 1055-1072.

[16] J. P. Fillastre, G. Viotte, J. P. Morin and B. Moulin, "Nephrotoxicity of Antitumoral Agents," Advances in Nephrology from the Necker Hospital, Vol. 17, 1988, pp. 175-218.

[17] L. S. Wood, "Management of Vascular Endothelial Growth Factor and Multikinase Inhibitor Side Effects," Clinical Journal of Oncology Nursing, Vol. 13, Suppl, 2009, pp. 13-18. http://dx.doi.org/10.1188/09.CJON.S2.13-18

[18] Y. Je, F. A. Schutz and T. K. Choueiri, "Risk of Bleeding with Vascular Endothelial Growth Factor Receptor Tyrosine-Kinase Inhibitors Sunitinib and Sorafenib: A Systematic Review and Meta-Analysis of Clinical Trials," The Lancet Oncology, Vol. 10, No. 10, 2009, pp. 967-974. http://dx.doi.org/10.1016/S1470-2045(09)70222-0

[19] Y. Wang, J. Gao, D. Zhang, J. Zhang, J. Ma and H. Jiang, "New Insights into the Antifibrotic Effects of Sorafenib on Hepatic Stellate Cells and Liver Fibrosis," Journal of Hepatology, Vol. 53, No. 1, 2010, pp. 132-144.

http://dx.doi.org/10.1016/j.jhep.2010.02.027

[20] M. Gabbianelli, E. Pelosi, E. Montesoro, M. Valtieri, L. Luchetti, P. Samoggia, L. Vitelli, T. Barberi, U. Testa, S. Lyman, et al., "Multi-Level Effects of Flt3 Ligand on Human Hematopoiesis: Expansion of Putative Stem Cells and pRoliferation of Granulomonocytic Progenitors/ Monocytic Precursors," Blood, Vol. 86, 1995, pp. 16611670.

[21] B. Uz, S. C. Tatonyan, M. Sayitoglu, Y. Erbilgin, O. H. Ng, Y. Buyukasik, N. Sayinalp, S. Aksu, H. Goker, O. I. Ozcebe, U. Ozbek and I. C. Haznedaroglu, "Local Hematopoietic Renin-Angiotensin System in Myeloid versus Lymphoid Hematological Neoplastic Disorders," Journal of Renin-Angiotensin-Aldosterone System, 2012, in press. http://dx.doi.org/10.1177/1470320312464677

[22] N. Kurikawa, M. Suga, S. Kuroda, K. Yamada and H. Ishikawa, "An Angiotensin II Type 1 Receptor Antago- 
nist, Olmesartan Medoxomil, Improves Experimental Liver Fibrosis by Suppression of Proliferation and Collagen Synthesis in Activated Hepatic Stellate Cells," British Journal of Pharmacology, Vol. 139, No. 6, 2003, pp. 1085-1094. http://dx.doi.org/10.1038/sj.bjp.0705339

[23] K. Funao, M. Matsuyama, Y. Kawahito, H. Sano, J. Chargui, J. L. Touraine, T. Nakatani and R. Yoshimura, "Telmisartan Is a Potent Target for Prevention and Treatment in Human Prostate Cancer," Oncology Reports, Vol. 20, 2008, pp. 295-300.

[24] M. M. Nagib, M. G. Tadros, M. I. Elsayed and A. E. Khalifa, "Anti-Inflammatory and Anti-Oxidant Activities of Olmesartan Medoxomil Ameliorate Experimental Colitis in Rats," Toxicology and Applied Pharmacology, Vol. 271, No. 1, 2013, pp. 106-113. http://dx.doi.org/10.1016/j.taap.2013.04.026
[25] K. Shimada, T. Murayama, M. Yokode, T. Kita, M. Fujita and C. Kishimoto, "Olmesartan, a Novel Angiotensin II Type 1 Receptor Antagonist, Reduces Severity of Atherosclerosis in Apolipoprotein E Deficient Mice Associated with Reducing Superoxide Production," Nutrition, Metabolism \& Cardiovascular Diseases, Vol. 21, No. 9, 2011, pp. $672-678$.

http://dx.doi.org/10.1016/j.numecd.2009.12.016

[26] P. Sengupta, U. Nandi and T. K. Pal, "Development of Safety Profile Evaluating Pharmacokinetics, Pharmacodynamics and Toxicity of a Combination of Pioglitazone and Olmesartan Medoxomil in Wistar Albino Rats," Regulatory Toxicology and Pharmacology, Vol. 62, No. 1, 2012, pp. 7-15.

http://dx.doi.org/10.1016/j.yrtph.2011.12.008 